\title{
Philosophy, Human Development and National Question
}

\author{
John Ekei \\ http://dx.doi./org/10.4314/ujah.v18i2.1
}

\begin{abstract}
What we know today as "philosophy" began as a cosmic inquiry into the nature of the universe as espoused by Thales of Miletus. Philosophy was then comparable to natural sciences; anchoring its major subject matter on the issue of change and permanence in the universe. The obvious discovery and wonder here, is that, behind this noticeable change in the universe, there is a certain unchangeable element, (urstoff). And the major problem becomes how this paradox of changeable and unchangeable phenomena can be resolved? While the solution to this dilemma is still being sought, Socrates shifted the attention of philosophy (with obvious reasons) from nature to ethical-political question, that is, to the issue of human development. It interests this essay, to find out, what exactly is human development, and why philosophy after Socrates considers human development as a more basic and more important issue than cosmic (or physical) development. In other words, why is human development the essence of every development and what is the contribution of philosophy to human development in Nigeria. And what is the relationship between philosophy, human development and national question in Nigeria fraught with corruption, insecurity, indiscipline, unemployment, etc.
\end{abstract}

\section{Introduction}

Heidegger's philosophy is an attempt to recognize the contributions of human beings or humanity to the understanding of 
creation. Human being has been a source of all creativity, interpretation, resourcefulness and inspiration that propel the development of a nation, like Nigeria. He is therefore, by virtue of his position, the architect of every nation building. In other words, human person is a being through whom other animate and inanimate creatures are explained, interpreted and accounted for. He not only takes care of himself but also, takes care of other creatures, events and establishments in nature. He is therefore a special breed, and made in the image and likeness of his creator ('imago Dei'). Thus, he is by vocation, the master of nature. Because of man's inestimable value, ('mma-ndu'), human welfare and development deserve by far a more considerable attention than other national and international considerations. His inestimable position is, perhaps why; Socrates re-directed the course of philosophical pursuit from cosmic-natural consideration to ethicalpolitical issues that concern human development. In other words, he shifted the cosmic question raised by the first philosopher, Thales, to "ethical-political question" that exclusively treats human development. And since that intervention of Socrates, human development has remained at the center stage of all philosophical inquiries.

In addition, a renowned Sophist, Protagoras, considers the immense resources in human being and declares that, "man is the measure of all things." (Skirbekk, 2001:35). For him, human being is a pacesetter of every physical and cosmic development found in every society. Based on this awareness, human development deserves more attention, more allocation of resources in the national budget than what is presently done in Nigeria as in many African countries. The issue of minimum wage is still at the level of debate. The unemployment of teaming number of youths has 
always been treated as trifling matter. The contention of this paper is that human development should attract more attention in Nigerian budget and allocations than other national issues. The lofty position of humanity should be kept in mind while undertaking national and international planning and executions. This is because all created things are animated, and given meaning by human interpretation. Human being and his development deserve more respect than they have been getting in actual life situation of Nigeria.

Certain issues that concern this all important development are what we consider as national question. Man remains the measure of all things, as Protagoras wants us to uphold. Hence, he is unarguably a privileged being, or a "fundamental ontology," as Heidegger would say. (Okere, 1983:36). For Immanuel Kant, every human being belongs to the "the kingdom of ends." He warned seriously that, in no circumstance, would man be used as a means to other's end. (Skirbekk, 282). All these allusions show that the development of human being must remain a priority in all national and international policies and deliberations. In this essay, our effort is to demonstrate that human development should be given more attention than ever before. All the issues that affect human development in Nigeria are here considered as a national question. They are questions that call for urgent solutions for the good of humanity. Most times, certain factors are found to be intrinsically and closely connected with human development. Hence, the lack of such factors tend to pose serious threat to humanity and more specifically, to human development. Philosophy has a long history in defense of human right, human development and human welfare. So, applying philosophy to human development in Nigeria cannot but remain a praiseworthy study and exploration. 
When Mr Ban Ki-Moon, the United Nations' Secretary General made a second historic visit to Nigeria which took place from Sunday, August 23 to Monday, August 24, 2014, he spoke to Nigerian governors on sustainable development. He tasks them on the provision of quality education, health and other dimensions. He states that "the governors have the power to make Nigerians feel the impact of democratic government by providing the enabling environment for quality education, health, and bearing in mind the climatic change."(Nigerian Guardian, 2015:1). He stresses that quality education, provision of health and adaptation to climatic change, etc, would drive African future to prosperity. In other words, Mr Ban Ki-Moon is pointing out the importance of human development (like, education and health) as a precondition for the attainment of other physical and national development.

In our own case, the government provision of human welfare and its satisfaction will determine the extent of social integration, social stability and good governance in Nigerian nation building. Here, the main requirements needed for human development seem to be partly identified by $\mathrm{Mr} \mathrm{Ki}-$ Ban Moon, the United Nations Secretary General. And they include the provision of quality education, health and control of climatic change. Quality education, judging from Nigerian present standard can hardly provide substantial human development. It is such that one may not be mistaken to request for education in Nigeria, before ever talking about quality education. In fact, they are two different things. What is called education in Nigeria presently is mere 'certificate education.' That type of education has been pejoratively tagged education as meal ticket, and nothing more. Nigerian education as we find it today does not integrate the inculcation of essential ingredients and intrinsic values needed for 
living in civilized society. It does give much emphasis to the integral human development. It does not provide programs for moral formation and authentic human existence. Nigerian education is not tailored towards inculcating social values needed for inter-personal and intra-personal relationships. The formation of citizens with great sense of responsibility, self reliance, self respect, respect for human right, and hard work is hardly included or emphasized in Nigerian system of education. The far reaching consequence of this vacuum shall be demonstrated in the subsequent sections.

On the contrary, what we call "quality education" is hardly acquired on the platter of gold. It is the effect of a well-planned and well-executed comprehensive tutoring by well selected enlightened and morally responsible teachers. The values mentioned above are indeed the integral part of human development. It is worthwhile that human beings (citizens) in Nigeria are carried along effectively by the government and its agencies, through the provision of welfare packages, and proper educational enlightenment. When this statutory function of the government towards its citizens is responsibly attended to, the government will soon reap the total confidence of its citizens. Failure to promote human development, especially through quality education, the government is seriously at the risk being sabotaged in its efforts towards effective governance. Is not this ugly scenario, the type picture we find in all sections of Nigeria today? The recurrent cases of vandalizing oil pipelines in Niger-Delta and tampering with electric wires in other parts of Nigeria is a ready example. In fact today, we are no longer talking about damaging the oil pipelines, but the issue of complete blowing up of the oil pipelines by new hoodlums that preferred to be called the 
"avengers." To forestall these evil tendencies, the government should endeavor, as a matter of urgency, to devote its efforts primarily to proper human development and its welfare. This project of promoting human development seems critical to the survival, flourishing and proper integration of every Nigerian in the task of nation building. In this paper, our effort will focus on exploring the meaning of human development and how philosophy can contribute towards human development in Nigeria. We shall equally explore how human development in Nigeria can accelerate the awareness and solution to the intractable Nigerian national question.

\section{The Concept of Human Development}

The term "development" in international parlance encompasses the need and the means by which nations provide better lives for their people. Development here includes not only economic growth, although that is crucial, but more importantly, the human development. Through this effort, health, nutrition, education, clean environment, etc, are provided. The basic attraction associated with the concept of development has boosted interest and aspiration of well meaning people, and civilized nations towards human development. This increased aspiration has made the issue of human development to assume a greater emphasis than any other kinds of development, physical or material. Human development has then become a significant value of no mean magnitude. Together with the pursuit of human rights, human development has become a value worth living for, and dying for. This desire to develop human being as to occupy his proper position in the scheme of things has enhanced nations' deliberate policies and action-plans towards human development. Much as 
certain efforts have been made to put in place human developmental programs in Nigeria, significant result has not been achieved. Presently, most Nigerian institutions of higher learning, carry cosmetic notifications often written in bold and conspicuous letters: "Say no to cultism," "Say no to exam malpractices", "Say no to prostitutions," "Say no to Drugs"!!, etc. So far, these cosmetic inscriptions have not made significant impacts on the lives of the students. They have hardly brought positive changes in their lives or significant transformation to their life styles. In his painstaking evaluation of the ugly situation, Heinecke avers that:

Nigeria no longer has an educational system but schooling system which does not merit the name of education because it systematically denies youth the most basic human rights to work, to stand on their own feet, to be self reliant and to support themselves and their community. (Heinecke, 1986:63).

The lesson elicited from this quotation is that countries where human development is not taken seriously, backwardness and retardation are evident among the youths. University graduates are supposed to possess basic right to work. With the skills acquired from education, they even can stand on their own feet. They supposed to be self-reliant without depending solely on the government for employment. Education supposed to offer them enough dispositions and skills to earn their living, to support themselves and their community. Unfortunately, the massive unemployed youths roaming Nigerian urban cities today is an objective pointer to the type of education the students were offered. It is a copious proof that the youth empowerment campaigns have not made much appreciable impact in the country. 
Here, it is believed that "the changes that are associated with development should provide the individuals and the societies with more control over their own destiny. Hence, both male and female, when properly trained and brought up; tend to contribute meaningfully with their diversity of talents to societal development." (Iwuoha, 2013:305).

C.B. Okolo presents the meaning of human development through education in this way, namely that, "education adequately nurtures the human mind and opens up horizons for creative or inventive spirit."(Okolo, 1994:98). Here, two concepts are important in the understanding of human development through education.

i) Education nurtures the human mind,

ii) Education enhances creative and inventive spirit,

These two factors expose what the citizens of a given country, should expect when there is effective and functional human developmental program in the country. As of now, the type of education conducted in Nigeria has been ineffective and has not been able to inculcate the above values in the citizens. The significance of this idea will be dramatically illustrated later in the course of our essay. Meanwhile, we return to the meaning of human development.

\section{The United Nations on Human Development}

United Nations Development Programme has been defining human development as "the process of enlarging people's choices." These choices entail allowing them to "lead a long and healthy life, to be educated, to enjoy a decent standard of living", as well as "political freedom, other guaranteed human rights and various ingredients of 
self-respect." (https//en.wikipedia.org/wiki/Human development (Humanity). In other words, human development entails:

i) The enhancement of healthy and long life,

ii) [Qualitative] education, means - the nurturing of human mind and enhancement of creative or inventive spirit,

iii) It entails political freedom which rejects all obstacles to man's exercise of his liberty. This includes freedom to do and achieve positive results, self actualization, invention and development.

iv) Human development also means the building of people's capacities, that is, the wide range of things people can do and achieve in life.

v) This means that human development is much more than economic growth which is only an aspect of enlarging people's choices.

Investing in human development enhances growth and empowerment of the citizens. It creates opportunity for the pursuit of different occupations in life. It enhances human capacities towards embracing various fields of endeavor. Through these varied means human beings actualize themselves in the world of limited resources. The end result of this process leads humanity to long and healthy lives. It also results in their being knowledgeable, to having access to the resources and social services needed for decent standard of living. It also increases their participations in the life of the community. We understand the broad expectations of human development as structured in its pillars. They include equality, sustainability, productivity, empowerment, cooperation and security. In other words, the identified pillars promote human development in the more significant ways. Equality implies the 
idea of fairness for every person, irrespective of male or female. Each person must have a right to education and health care among others. Sustainability empowers both sexes to have the right to earn a living that can sustain lives and also, the right to the distribution of goods. Productivity entails the full participation of the individuals in the process of income generation. It also implies that government should provide social programs and the enabling environment where people can exercise their right of income generation.

Empowerment includes the freedom of the people to influence development and decisions that affect their lives and their wellbeing. Cooperation enjoins participation and belongingness to communities and groups, as a way of mutual enrichment and socialization. Security is an assurance to human beings that their hard earned goods and services are fully protected now and in future times. These factors have a way they help in sustaining the protection and flourishing of human development, especially in Nigeria. Now, let us examine the task philosophy shares uniquely in the comity of other intellectual disciplines in fostering human development.

\section{The Role of Philosophy on Human Development in Nigeria}

We have exposed the meaning of philosophy as well as human development. We are able to discover that different indices that make up the understanding of human development include: provision of health, leading to long life, political freedom, building people's capacities, and education, especially the nurturing of human mind, etc. The question now concerns how philosophy, as a critical and reflective study can facilitate the enhancement of these factors of human development. In other words, what contribution 
does philosophy make in the promotion of human development in Nigeria?

As an intellectual discipline, the subject matter of philosophy covers all the domains of human existence including the issue of human development and human rights. That is why we have philosophy of different disciplines in academic circles. Hence, there is philosophy of science, philosophy of law, philosophy of technology, philosophy of humanities, philosophy of development, philosophy of education, philosophy of mind, etc. Of all these roles, philosophy plays a more significant function in the search for human development through the molding of people's minds and mindsets. The basic reason why the molding of minds is the most important function of philosophy is because human mind, like automobile engine tends to control and influence other parts of the body. The English proverb has it that a healthy mind in a healthy body. In other words, a healthy mind brings about a healthy body. It is just like saying a sound motor engine reflects the sound condition of the entire vehicle. In other words, philosophy helps in the development of a healthy mind in a person. It helps in the cultivation of rational, reflective and critical mind. Besides, philosophy facilitates the development of creative, innovative and inventive qualities in human being.

J. Omoregbe avers that the issue of meaning of philosophy and its relevance " ... is an important question, [particularly] in Africa today, when most African political leaders erroneously conceive 'national development' in terms of economic, technological, scientific development, or in terms of productivity of material goods, with little or no attention paid to the development of human person." (Cf, Ekei, 2014: viii). And to talk about the human 
person at all, is to talk about the human mind that controls the overall activities of a person. It is human mind that controls and facilitates the activities of humanity as a whole. Remove human mind (that invisible body engine) the success story of humanity becomes an illusion. In fact, right from the time of Socrates, Stoics, Plato, Aristotle up to Descartes, the entire human person is conceived to be encapsulated in human soul. In other words, human mind can as well represent the human person. For Plato, human mind is likened to charioteer [the pilot] dragging the two horses: spirited and the appetitive horses.(Copleston, 1962:235). That is, the human mind controls and influences the good and evil part of the human body. For Rene Descartes, human being can as well be referred to as "a thinking being," that is, 'a res cogitans.' (Skirbekk \& Gilje, 2001:196). Because of the inestimable value of human person, represented in human mind, Socrates shifted philosophical inquiry from the study of nature (the cosmos) to the study of human being. Philosophy therefore upholds that human mind is essentially what makes human being what he or she is.

So, in the hierarchy of different ingredients that constitute human development, qualitative education that nurtures the human mind to its height occupies the primary consideration. The role of philosophy, therefore, is principally found in the cultivation and nurturing of human mind. In his effort to emphasize the importance of this cultivation of mind, (an essential part of human development), a renowned British philosopher, Bertrand Russell rightly remarks that:

If all men were well off, if poverty and disease had been reduced to lowest possible point, there would still remain much to be done to produce a valuable society and even in 
the existing world, the goods of the mind are at least as important as the goods of the body.( Russell, 1976:89).

In reference to the above insight, Russell teaches that, it is in the development of human mind that philosophy contributes its major role to human development. Some critics like W. Halverson conceive philosophy as possessing no practical relevance. They see philosophy as dealing on abstract issues that have nothing to show for its existence. Here, Halverson seems very emphatic, as he argues that: "Scientists and technicians do things that help to produce the necessities and comforts of life; doctors and dentists work to alleviate human suffering; athletes and musicians provide enjoyable entertainment-but what do philosophers do for their fellow men?" (Halverson, 1954:6).

Philosophers from Socrates, Plato, Aristotle, up to Descartes have always argued to the contrary that the dignity of human beings lies in the mind and not in their body- make ups. The mindset of a people makes a difference in the way and manner they approach life in general. It makes a significant difference in the way and manner they interact with their fellow human beings. The mind set controls a human being, just as the steering controls the vehicle. The mindsets dictate how a people react to issues, and how they exercise their responsibilities. If the mindset of Nigerians is positively nurtured, it will show in the qualitative way they respect the established values and heritages of the society. It will influence how they observe the laws and norms of the land, etc. Again, if the mindsets of average Nigerians are morally cultivated, there would be mutual respects for human persons in both public and private sectors. Crimes will be drastically reduced in the society. Governance will no longer be an avenue of siphoning nation's 
limited resources and storing them in foreign banks. Hence, for human development, to thrive the mindsets of those that govern Nigeria must be formed and imbued with moral and intellectual visions. This is where the critical and reflective disposition of philosophy plays a fundamental role to human development. In fact, people with developed mindsets appreciate clean environments. This is because healthy environments lead to good health and long life. People that cultivate sound moral principles ensure that others enjoy healthy environments as well as political freedom and satisfaction. Such few group of people are more disposed than others towards assisting their fellow citizens to build and develop their own capacities. They are disposed and ready to help them through creation of enabling environments for quality education, and other empowerments.

Because of the underlying power of philosophy to human development, every academic discipline in Nigerian universities and other parts of the world bears the stamps of philosophy. Hence, we have philosophy of every discipline, like philosophy of education, philosophy of science, philosophy of law, philosophy of medicine, etc. Besides, it is also a fact of history that the highest degree offered by universities all over the world bears the established ancestral stamp of "Doctor of Philosophy", Ph.D. That is again, a pointer to the indispensable role of philosophy to human development.

\section{Human Development and National Question}

In respect to human development, certain factors militate against the sustained welfare of human beings living in Nigeria. These mitigating predicaments are presented here as Nigerian national 
question. National questions usually raise critical questions in the minds of many Nigerians. Such questions are what Chinua Achebe insinuates where he observes that:

Whenever two Nigerians meet, their conversation will sooner or later slide into litany of our national deficiencies. The trouble with Nigeria has become the subject of our small talk in much the same way as the weather is for the English. (Achebe, 1983:2).

The leadership problem is one of such nagging issues that usually raise million questions in minds of many Nigerians, especially among the political class. Other issue concerns the geo-political imbalance in Nigeria. There are also the federal character sages, the problem of resource control and revenue allocations. These factors have constituted what many Nigerians consider as the national questions. But in the present dispensation, they are not the only problems plaguing Nigeria as a country. Other national questions abound. In fact, they are considered as national questions because the issues involved are consistently challenging not only the unity of Nigeria but also the welfare of her citizens. In a multiethnic country like Nigeria, the issue of distributive justice, fairness and equity also constitutes the national questions. It borders on the best sharing formula that will satisfy the multifarious composition of Nigeria.

Therefore, "Nigerian national question," broadly speaking, concerns whatever constitutes serious problems, and raises serious challenges concerning the welfare of human beings, living in Nigeria. This includes the intractable socio-political, religious, environmental or ethical predicament in which our nation finds 
itself. For according to Aristotle, "the very reason for the existence of the state, [as well as politics, government or leadership] is for the sake of good life." (Aristotle, 1252b-27-30). In other words, whatever contravenes the welfare of Nigerians significantly constitutes the issue of national question.

The good life/welfare of humanity is articulated by United Nations Development Programme as made up of "the process of enlarging people's choices." Choices when properly made will "lead to a long and healthy life, to achieving education, to enjoyment of a decent standard of living", to political freedom, as well as to other guaranteed human rights and various ingredients of self-respect." In order to attain the integral decent life which human development requires the government should plan and work towards achieving long and healthy life of Nigerian citizens. Besides, the government will equally pay attention to the quality of its education, and discipline. It must find ways of fighting corruption, climate change, environmental hygiene, and of course, security. These factors and more are encapsulated under the banner of Nigerian national question. We take time to examine these factors beginning with the following, namely:

\section{Effects of (Quality) Education on Human Development in Nigeria}

John Dewey, the foremost American philosopher of education defines the task of education as "an emancipation and enlargement of experience." (Okolo, 49). Education frees human beings from prejudices and irrational assumptions of everyday life and enlarges their experiences. Based on the above functions, Francis Bacon dramatizes the role of education in terms of "power" to master and interpret one's environment. For him, "knowledge is power." That 
is, knowledge provides the free and comprehensive development of human powers, especially the power of the mind. In fact, if the mindsets of Nigerians are positively and constructively directed, the citizens will respect the Common good and government facilities put in place for human development. Generally speaking, a positive disposition towards the Common good has not been a consistent habit of average Nigerians. Most times, lack of electricity in many parts of Nigeria is as a result of people who vandalize electric wires, electric poles or even electric transformers.

Public pumps and bore holes are not spared. Oil pipe lines are tampered with on daily basis. Roads and drainages are either destroyed or they are filled up with sand and pebbles. Most of these maladies are committed for selfish reasons. For paltry profits, the entire community is thrown into total darkness due to vandalizing of electric facilities. Some hoodlums vandalize oil pipelines for the same selfish reasons. Broadly speaking, ignorance is said to be at the root of these social maladies. Sometimes, when government facilities are destroyed in this way, the easiest factor to blame is sabotage or the antics of political enemies. But the main reason underlying all these evil is ignorance arising from mental depravity. It is the problem of undeveloped and uncivilized mindsets which dominate the attitude of a people.

Perhaps, certain illustration can help in showing how untrained mindsets of many Nigerians have retarded the pace of human development. Dr B. Ewelu reflected on the state of roads and drainages in Nigeria with particular reference to Anambra State, precisely, Okpuno town. In his recent Rector's address at Pope John Paul II Memorial lectures, organized by the staff and 
Seminarians of the institution, Rev. Fr. Dr. B. Ewelu regretted the [present] condition of [well constructed] roads in Anambra state. He pointed out that, "it is all saddening because Anambra State Government has spent fortunes to construct good roads. The citizens have filled up the drainages with refuse, sands and stones. They have filled up the roads and streets with their goods for sales, with parked motorcycles (Okadas) and kekes, thereby narrowing the roads to nothing better than pathways." (Ewelu, 2016:1). He goes on to say that the well- meaning people "were of the opinion that it was a big mistake to have constructed these roads and streets without first and foremost building the minds of the citizens that would make use of the facilities." He finally concluded that, "it would seem that Anambra State Government placed the cart before the horse in this case. The argument is that it is a fundamental mistake on the part of the government to have constructed the roads and drainages without first educating the citizens that would make use of the roads and gutters. The society cannot build without first building the minds of its citizens.” The Nigerian question here is on how to cultivate the minds of average Nigerian to have a rethink, a wider vision concerning what promotes his own very welfare.

This is a clear example of the impact of the citizens' negative mindsets on the efforts of the government towards human development and welfare. The solution begins with quality education that inculcates strong moral values needed for life in the society. Life in human society can never be an arbitrary activity. There must be an inculcation of morals and norms the society. There must be an inculcation of a sense of relatedness and belongingness of human beings living within the society. (Ekei, 1). Proper response to Nigerian question therefore will demand 
selflessness on both leadership and followership. It will require a sense of patriotism, justice, honesty, hard work, responsibility, respect for human right and human freedom, etc. Anambra State Government provided good network of roads and drainages. But the citizens degraded the facilities due to irresponsible mindsets. Quality education can provide solution to Nigerian question. And because the citizens have not been given proper quality education [which begins with reshaping their mindsets], they end up destroying the physical structures put in place for them by the government. This comes to confirm that human formation and enlightenment must be taken care of first. This formation will then guarantee and safeguard any physical development that is put in place by the government. This aspiration can be achieved through many avenues, some of which are discussed below.

\section{Level of Discipline}

Human development is expressed also in the level of discipline the citizens of a given country, like Nigeria exhibit in their day to day encounter with the environment. Where the average citizens are disciplined, we expect a high degree of social integration and respect for common good of the nation. Different levels of development, human, physical, and environmental development will be evident, etc. In other words, the dividends of disciplined can hardly be over emphasized. In fact, nation building is all about the amount of discipline exhibited by the citizens while carrying out their legitimate duties. In fact, Nigerian national question is a quest towards building a virile nation that is economically buoyant and socially integrative. When nation building has attained the level of success, it ushers in a quantum of good life for the citizens. 
Presently, Nigeria is witnessing a steady decline in the level of discipline of its citizens. Chinua Achebe defines indiscipline as "a failure or refusal to submit one's desires and actions to the restraints of orderly social conduct in recognition of the rights and desires of others." (Achebe, 1983:27).

In 2014, the Nation, Daily Newspaper reported that, "there is a growing and justified local and international concern about public corruption in Nigeria."(Nation Newspaper, 2014:72). On its own, Transparency International has indicted Nigeria of financial mismanagement and indiscipline. In its annual reports, this global anti-corruption organization has consistently ranked Nigeria lowest in the global country league of transparency. (Ekei ${ }^{2}, 2013: 28$ ). Chinua Achebe plainly asserts that indiscipline is endemic in Nigeria:

It pervades our life so completely today that one may be justified in calling it the condition par excellence of contemporary Nigerian soceity. We see and hear and read about indiscipline in the home, in the school, in the public service, in the private sector..., etc. (Achebe, 27).

So, human development is better assured in Nigeria when the citizens are treading the path of probity and moral rectitude. It is all about accountability that results in provision of better welfare packages for the individuals in the society.

\section{Patriotism}

No country can boast of human development without the effective contributions and sacrifices of its citizens. Patriotism implies the love of one's fatherland and the readiness to defend it. Nigerians 
should cultivate this love of fatherland so as to maximize both physical and human resources for human development. The task of nation building that assures human development demands all hands to be on deck. That is why the former American President, John Kennedy puts it forward to the Americans to "ask not what the country can do for them but what they can do for the country." (Okolo, 77). In fact, patriotism is a rare virtue among Nigerians; that is why corruption is at its highest level in Nigeria. Lack of patriotism in Nigeria today comes as the effect of ignorance, narrow-mindedness, nepotism, selfishness and backwardness. Consequently, an individual in Nigeria ought to be educated not only on the nature of his rights in the society but also on his fundamental obligations to the society. Here, patriotism is perhaps the most basic of all obligations towards the state. It is when the government is empowered with various resources, sacrifices, inputs, efforts and love of its citizens, that it can better offer effective services to human welfare in Nigeria.

\section{Philosophy, Human Development and National Question}

It is interesting to examine, at this juncture, no matter how briefly, the relationship that exists among the three variables; namely, "philosophy", "human development" and the "national question" in Nigeria. By virtue of its basic function as a reflective and critical science, philosophy has achieved a history in creating the consciousness that is needed for positive changes in human outlook. It ushers the awareness concerning the sublime nature of man, (mma-ndu) and the best way to attain relationship with him. Philosophy also provides the critical insight towards improving his condition. In fact, human development is the fulcrum and soul of every philosophic reflection. Unfortunately, Nigeria has steadily trivialized the provision of human developmental schemes. It has 
failed to appreciate the relationship that exists between the human resource development and improved physical resources. It has failed to appreciate that human resource is the primary agent and the catalyst of every development. This lack of appreciation concerning their inner link and interconnection is perhaps contributive to consistent human right violation, abuse, and denial in Nigeria. It is also at the root of the noticeable apathy towards providing qualitative education for him. The incessant strike by the academic staff union of universities (ASUU) to protest the gross inadequacies in the academic environments in Nigeria is a case in point. Apart from deficiency in qualitative education, political violence in Nigeria exposes human beings to great danger each time it occurs. The economic sphere has not spared the average Nigerian from exploitations and inflations.

In short, the image of humanity has been terribly distorted in our contemporary scene. In other words, the best option is the affirmation that Man is defiled, devalued and degraded in our contemporary Nigeria. The situation naturally and inevitably raises the national questions. In fact, to talk about the injury inflicted to humanity by Boko Haram terrorists, is to forget the rampant cases of kidnapping episode. The issue of rape and domestic violence against women has been on the increase these days. It again betrays the glaring inadequate appreciation of human dignity and its development in Nigeria. There is also the issue of unpaid salaries of workers, the minimum wage saga, etc. All these maladies are associated with unschooled mindsets of many contemporary Nigerian leaders. It is incumbent on philosophy therefore to instill a total change in outlook concerning the way human beings are viewed and treated presently. Philosophy has insisted that every human being in so far as he or she is a human 
person deserves to be regarded and treated as a kingdom of ends. "Since the fundamental rationale behind any changes in the world outlook is principally a philosophical matter," (Wiredu, 1980: x), the relevance of philosophy to humanity and human development in Nigerian becomes easily understandable. In fact, philosophy undertakes this change in human outlook through creation of basic awareness that leads to a positive change of mindsets among Nigerians. With the positive change of mindset and attitudes, most of the social ills in Nigeria as highlighted above will be highly reduced, if not completely abolished.

And once philosophy succeeds in changing the mindset of average Nigerian while imbuing it with positive and constructive exactness, the issue of providing solutions to other national questions will be taken care of. This is because human beings have proved themselves as gifted with amazing potentialities. Man is after all a bundle of possibilities in accomplishments. The only instrument he needs is a good disposition of mindset and discipline. The average Nigerians need to be given a qualitative education that brings about a positive change of mindset. In its turn, the positive mindset will secure the common good and create effective direction towards the practical exploration of the wealth of the nation. From the foregoing, we discover that there is an implicit relationship among the three variables of philosophy, human development and national question. This relationship can be likened to the relationship between the cause and its effect. Philosophy creates awareness and changes the mindset. With change of mindset, human beings are better disposed to respect the natural and physical resources of the country and imbibe the virtue of hard work and patriotism. The sense of hard work and patriotism will then provide the means of tackling the national questions. The national question provides 
wherewithal or the raw materials for philosophical reflection and intervention.

\section{Conclusion}

In conclusion, we have here, the opportunity to revisit the essential points of what the United Nations Development Programme says concerning human development. It defines human development as the process of enlarging people's choices. Choices when properly enlarged leads to long and healthy life. Choices bring about the possibility of being educated, of enjoyment of a decent standard of living, etc. There is also the value of political freedom, as well as other guaranteed human rights and various ingredients of selfrespect that usher human development." Ordinarily, everybody chooses what he or she feels that brings him maximum happiness. Sometimes, what one chooses for happiness may turn out to bring misfortune and sorrow. That notwithstanding, human development implies that people are provided freedom, not only to make their choices but also to find a way of broadening and improving their conditions. The end result of good choices is the ultimate realization of long and healthy life or what Aristotle calls the provision of good life for man.

Going by what is studied above; good choices presuppose welldisposed and enlightened mindset that is founded on good attitudes to life. We mentioned some indices that lead to well-enlightened mindset. One of such indices includes quality education that incorporates civic, ethical and moral values. Other factor includes a keen sense of discipline that eschews corruption, irresponsibility, indolence and dishonesty. Another factor mentioned above is patriotism. This virtue is a disposition in a person who makes sacrifices and exhibits high sense of loyalty for the love of his own 
fatherland. A patriot is a symbol of many praiseworthy qualities mentioned above. Patriotism is an indispensable quality that improves humanity and human development, especially in Nigeria.

Other noble qualities mentioned include the sense of honesty, accountability, faithfulness, etc. We will not forget a disposition of togetherness, of peaceful coexistence, and belongingness of human beings. Included is a sense of justice and fairness in dealing with human beings irrespective of their ethnic, political and religious affiliations. This general vision was what marked the average African in the traditional setting. It inspired loyalty to ones community and respect for its common good. Julius Nyerere of Tanzania re-echoes this common vision as found in traditional Africa when he admonishes the contemporary Africans towards self recovery insisting that,

Our first step (in the effort towards human development) therefore must be to re-educate ourselves to regain our former attitude of mind. In our traditional African society, we were individuals within a community. We took care of the community and the community took care of us. (Nyerere, 1974:6).

\section{John Ekei}

Pope John Paul II Major Seminary

Awka

bjchialuka@yahoo.com 


\section{References}

Achebe, (1983), The Trouble with Nigeria, Enugu: Fourth Dimension Publishers.

Aristotle, (1993), Politics, 1252b-27-30 quoted from C.B. Okolo, African Social and Political Philosophy: Selected Essays, Nsukka: Fulladu Publishers.

Burtt. E, (1967), In Search of Philosophic Understanding, New York: Mentor Book Publication.

Coplestone. F. (1962), A History of Philosophy, (Ancient), New York: Image Book Publishers.

Ekei. J, (2015), "The Problems and Challenges in African Philosophy" in Discourse in African Philosophy, Awka: Smagh Press.

Ekei. J, (2013), "The Task of Nation Building in Multi-ethnic Nigeria: Problems, Prospects and Philosophical Implications" in The Humanities and Nation Building, Awka: Fab Anieh Publishers.

Ewelu, B, (2016), "Rector's Address," presented at the $11^{\text {th }}$ Pope John Paul II Memorial Lectures at Pope John Paul II Major Seminary, Awka, $19^{\text {th }}$ April.

Heinecke. P, (1986), Freedom In The Grave, (1986), Okpella: S. Asokome and Co. Publishers.

Halverson. W, A, Concise Introduction to Philosophy,( 1959),

New Haven and London: Yale Publishers, pp.6-7 quoted from Ewelu.B, (2009), "Relevance of Philosophy" in Philosophy: of What relevance? Enugu: Delta Publications. Iwuoha. C, (2013), "Gender Identity and Social Stability as a basis for social development" in Humanities and National Identity.

Nigerian Guardian News Paper, (2015), Monday, August 24, pp. 12. 
Nation, Daily News paper, (2014), Vol.9, No. 2,800, p.72.

Nyerere. J, (1974), Ujamma- The Basis of African Socialism, DarEs-Salaam: Oxford University Press.

Okere, T., (1983), African Philosophy: A Historico- Hermeneutical Investigation of the Condition of its Possibility, University Press of America.

Okolo. C. (1994), Squandermania Mentality: Reflections On Nigerian Culture, Enugu: University Trust Publishers.

Popkin, et al, (1993), Philosophy Made Simple, New York: Double Day Publishers,

Jaspers K, Way To Wisdom, (1975), New Haven: Yale University Press.

Russell. B, (1976), The Problems of Philosophy, New York: Oxford University Press.

Skirbekk, G,et al. (2001), A History of Western Thought, New York: Routledge Publishers,

Wiredu, K, (1980), Philosophy and an African Culture, New York: Cambridge University Press. 